\title{
Tumor Necrosis Factor- $\alpha$ Modulates Survival, Proliferation, and Neuronal Differentiation in Neonatal Subventricular Zone Cell Cultures
}

\section{Liliana Bernardino, fabienne Agasse, Bruno Silva, Raquel Ferreira, Sofia Grade, Joũo O. Malva}

Neuroprotection and Neurogenesis in Brain Repair Group, Center for Neuroscience and Cell Biology, Institute of Biochemistry, Faculty of Medicine, University of Coimbra, Coimbra, Portugal

Key Words. Tumor necrosis factor- $\alpha \cdot$ Neuronal differentiation $\bullet$ Subventricular zone $\bullet$ Calcium imaging $\bullet$ Histamine $\bullet$ Neurogenesis

\begin{abstract}
Tumor necrosis factor (TNF)- $\alpha$ has been reported to modulate brain injury, but remarkably, little is known about its effects on neurogenesis. We report that TNF- $\alpha$ strongly influences survival, proliferation, and neuronal differentiation in cultured subventricular zone (SVZ) neural stem/progenitor cells derived from the neonatal P1-3 C57BL/6 mice. By using single-cell calcium imaging, we developed a method, based on cellular response to $\mathrm{KCl}$ and/or histamine, that allows the functional evaluation of neuronal differentiation. Exposure of SVZ cultures to 1 and $10 \mathrm{ng} / \mathrm{ml}$ mouse or $1 \mathrm{ng} / \mathrm{ml}$ human recombinant TNF- $\alpha$ resulted in increased differentiation of cells displaying a neuronal-like profile of $\left[\mathrm{Ca}^{2+}\right]_{i}$ responses, compared with the predominant profile of immature cells observed in control, nontreated cultures. Moreover, by using neutralizing antibodies for each TNF- $\alpha$ receptor, we found that the proneurogenic effect of $1 \mathrm{ng} / \mathrm{ml}$ TNF- $\alpha$
\end{abstract}

is mediated via tumor necrosis factor receptor 1 activation. Accordingly, the percentage of neuronal nuclear protein-positive neurons was increased following exposure to mouse TNF- $\alpha$. Interestingly, exposure of SVZ cultures to $1 \mathrm{ng} / \mathrm{ml}$ TNF- $\alpha$ induced cell proliferation, whereas 10 and $100 \mathrm{ng} / \mathrm{ml} \mathrm{TNF}-\alpha$ induced apoptotic cell death. Moreover, we found that exposure of $\mathrm{SVZ}$ cells to TNF- $\alpha$ for 15 minutes or 6 hours caused an increase in the phospho-stress-activated protein kinase/c-Jun N-terminal kinase immunoreactivity initially in the nucleus and then in growing axons, colocalizing with tau, consistent with axonogenesis. Taken together, these results show that TNF- $\alpha$ induces neurogenesis in neonatal SVZ cell cultures of mice. TNF- $\alpha$, a proinflammatory cytokine and a proneurogenic factor, may play a central role in promoting neurogenesis and brain repair in response to brain injury and infection. STEM CELLS 2008; 26:2361-2371

Disclosure of potential conflicts of interest is found at the end of this article.

\section{INTRODUCTION}

In the adult brain, neurogenesis occurs constitutively in two defined regions: the subgranular zone of the hippocampus and the subventricular zone (SVZ) lining the lateral ventricles. Neural stem cells (NSCs) located in the SVZ proliferate and give rise to neuroblasts that migrate toward the olfactory bulb, where they differentiate into interneurons [1-5]. This robust process, giving rise to a constant neuronal replacement of olfactory interneurons, highlights the potential of SVZ cells for future stem cell-based brain repair strategies.

Upon brain injury, newly generated neuroblasts migrate out of the SVZ toward the damaged areas of the brain [6-12]. Injury-enhanced neurogenesis relies in part on soluble mediators released by damaged tissue and activated immune cells. In particular, inflammatory cytokines, abundantly secreted following brain injury or infection, may influence neurogenesis [13$16]$. Among these inflammatory mediators, tumor necrosis fac- tor (TNF)- $\alpha$ is a crucial effector of immune responses in the brain $[17,18]$, mediating distinct cellular effects through two different receptors: tumor necrosis factor receptor (TNFR) 1, which contains an intracellular "death domain" and contributes mainly to neuronal death, and TNFR2, which contributes mainly to neuroprotection [19-22]. Recent reports suggest that TNF- $\alpha$ can also modulate neurogenesis. Indeed, neural stem/progenitor cells express TNF- $\alpha[23,24]$ and its receptors [24-28].

It has been reported that $\mathrm{TNF}-\alpha$ regulates survival of NSCs. However, recent studies have shown that TNF- $\alpha$ contributes to the death of hippocampal progenitor cells [26] and mousederived SVZ neurospheres in vitro [29]. In contrast, few apoptotic cells were found in the SVZ of TNF- $\alpha$-treated rats, where an increase in proliferation was observed in vivo in basal conditions [30]. Moreover, in vivo infusion of a neutralizing antibody against TNF- $\alpha$ reduced the number of new striatal and hippocampal neuroblasts generated after stroke [31].

Several lines of evidence have also implicated TNF- $\alpha$ in proliferation of NSCs in the intact and in the injured brain. In

Author contributions: L.B. and F.A.: conception and design, collection and/or assembly of data, data analysis and interpretation, manuscript writing, final approval of manuscript; B.S., R.F., and S.G.: collection and/or assembly of data, data analysis and interpretation; J.O.M.: conception and design, financial support, administrative support, data analysis and interpretation, manuscript writing, final approval of manuscript.

Correspondence: João O. Malva, Ph.D., Center for Neuroscience and Cell Biology, Institute of Biochemistry, Faculty of Medicine, University of Coimbra, 3004-504 Coimbra, Portugal. Telephone: 351-239-112254; Fax: 351-239-822776; e-mail: jomalva@fmed.uc.pt Received October 30, 2007; accepted for publication June 8, 2008; first published online in STEM CELLS EXPRESS June 26, 2008. CAlphaMed Press 1066-5099/2008/\$30.00/0 doi: 10.1634/stemcells.2007-0914 
particular, it has been shown that mice lacking TNF- $\alpha$ had a significant reduction of the pool of proliferating oligodendrocytes and a subsequent delay in remyelination in a mouse model of demyelinating diseases [32]. Furthermore, Widera et al. [28] showed that nuclear factor $\kappa \mathrm{B}$ and cyclin D1 play a crucial role in the proliferation of NSCs induced by TNF- $\alpha$ in vitro. However, TNF- $\alpha$ was found to inhibit proliferation of TNFR1expressing striatal neural progenitors in vitro [25]. In accordance, by using mice lacking TNF- $\alpha$ receptors, Iosif et al. showed that TNFR1 acts as a suppressor of progenitor proliferation both under basal conditions and after onset of status epilepticus, whereas TNFR2 can improve survival of the newly formed neurons in the pathological brain in vivo [24]. Moreover, TNF- $\alpha$ was shown to stimulate neuronal differentiation of immature neural cells and neuroblastoma cell lines infected with HIV-1 [33, 34].

In the present report, we dissect the effects of TNF- $\alpha$ on neurogenesis in mouse SVZ cultures by using a novel method able to functionally discriminate neuronal differentiation. Moreover, we investigated the involvement of the stress-activated protein kinase (SAPK)/c-Jun N-terminal kinase (JNK) signaling pathway in response to TNF- $\alpha$ exposure and the interplay between cell death and proliferation. Taken together, our results open a new perspective for TNF- $\alpha$ as a proneurogenic factor, able to facilitate neuronal replacement and brain repair in response to brain injury.

\section{MATERIALS AND METHODS}

All experiments were performed in accordance with European Union (86/609/EEC) guidelines for the care and use of laboratory animals.

\section{Subventricular Zone Cell Cultures}

SVZ cells were prepared from 1-3-day-old C57BL/6 donor mice as described by Agasse et al. [35]. Briefly, mice were killed by decapitation, and the brains were removed and placed in calciumand magnesium-free Hanks' balanced saline solution (Gibco, Rockville, MD, http://www.invitrogen.com) under sterile conditions. Fragments of SVZ were dissected out of $450-\mu \mathrm{m}$-thick coronal brain sections by using a Mcllwain tissue chopper, and then SVZ was digested in $0.025 \%$ trypsin (Gibco) and $0.265 \mathrm{mM}$ EDTA (Gibco) $\left(10\right.$ minutes, $\left.37^{\circ} \mathrm{C}\right)$, following by mechanical dissociation with a P1000 pipette. The cell suspension was diluted in serum-free medium (SFM) composed of Dulbecco's modified Eagle's medium (DMEM) (DMEM/Ham's F-12 medium + GlutaMAX-I) supplemented with $100 \mathrm{U} / \mathrm{ml}$ penicillin, $100 \mu \mathrm{g} / \mathrm{ml}$ streptomycin, $1 \%$ B27 supplement, $10 \mathrm{ng} / \mathrm{ml}$ epidermal growth factor, and $10 \mathrm{ng} / \mathrm{ml}$ basic fibroblast growth factor-2 (all from Gibco). Single cells were then plated on uncoated Petri dishes at a density of 3,000 cells per $\mathrm{cm}^{2}$ and were allowed to develop in an incubator with $5 \% \mathrm{CO}_{2}$ and $95 \%$ atmospheric air at $37^{\circ} \mathrm{C}$.

Six to 8 days after plating, the SVZ neurospheres were collected and seeded onto poly-D-lysine $(0.1 \mathrm{mg} / \mathrm{ml})$-coated glass coverslips, placed into 12-well cell culture plates for single-cell calcium imaging (SCCI) experiments or 24-well cell culture plates for immunocytochemistry, and covered with $1 \mathrm{ml}$ or $500 \mu \mathrm{l}$, respectively, of SFM devoid of growth factors. Then, SVZ neurospheres were allowed to develop for 2 days with $5 \% \mathrm{CO}_{2}$ and $95 \%$ atmospheric air at $37^{\circ} \mathrm{C}$ before experimental treatments. A scheme of the protocol is provided in Figure 2A.

\section{Experimental Treatments}

To investigate the influence of TNF- $\alpha$ on neuronal differentiation, SVZ neurospheres were allowed to develop for 7 days with recombinant mouse $(0.3,1,10$, and $100 \mathrm{ng} / \mathrm{ml}$; R\&D Systems Inc., London, http://www.rndsystems.com) or human (1 ng/ml; Peprotech, London, http://www.peprotech.com) TNF- $\alpha$ at $37^{\circ} \mathrm{C}$. To de- termine which TNF- $\alpha$ receptor was involved in the proneurogenic effect, SVZ cells were treated with $1 \mathrm{ng} / \mathrm{ml}$ mouse TNF- $\alpha$ together with $20 \mu \mathrm{g} / \mathrm{ml}$ neutralizing mouse monoclonal anti-TNFR1 or with $20 \mu \mathrm{g} / \mathrm{ml}$ neutralizing mouse monoclonal anti-TNFR2 antibodies [36] (both from R\&D Systems). In a group of experiments, SVZ cells were treated with a neutralizing antibody against TNF- $\alpha$ (81 $\mu \mathrm{g} / \mathrm{ml}$; Upstate Biotechnology, Lake Placid, NY, http://www. upstate.com). At the end of treatments, SCCI experiments and immunocytochemistry for neuronal markers (neuronal nuclear protein $[\mathrm{NeuN}]$ and microtubule associated protein-2 [MAP-2]) were performed (Fig. 2A). To dissociate the apoptotic effect of TNF- $\alpha$, SVZ cells were coincubated for 48 hours with $10 \mathrm{ng} / \mathrm{ml}$ TNF- $\alpha$ and $25 \mu \mathrm{M}$ z-Val-Ala-DL-Asp (OMe)-fluoromethylketone (zVAD-fmk; Calbiochem, Nottingham, U.K., http://www.emdbiosciences.com), a pan-caspase inhibitor used as an antiapoptotic agent.

To investigate the involvement of the SAPK/JNK signaling pathway in response to TNF- $\alpha$ stimulation, SVZ neurospheres were treated with 1,10 , or $100 \mathrm{ng} / \mathrm{ml}$ mouse recombinant TNF- $\alpha$ for 15 minutes or 6 hours at $37^{\circ} \mathrm{C}$. At the end of each incubation protocol, immunocytochemistry against phosphorylated (activated) forms of the SAPK/JNK kinase, namely P-SAPK/JNK, was performed (Fig. 2A). Each experiment included a series of control cultures not subjected to any drugs.

\section{Determination of Cell Apoptosis by Terminal Deoxynucleotidyl Transferase dUTP Nick-End Labeling}

Cell apoptosis in SVZ cells was evaluated by the terminal deoxynucleotidyl transferase dUTP nick-end labeling (TUNEL), essentially as previously reported [35]. This method is based on the specific activity of TdT, which attaches labeled nucleotides (dUTP) to the 3'-OH ends of the DNA generated during apoptotic-induced DNA fragmentation [37]. At the end of each TNF- $\alpha$ incubation protocol (48 hours), SVZ cultures were fixed for 30 minutes in $4 \%$ paraformaldehyde (PFA) at room temperature, rinsed in $0.15 \mathrm{M}$ phosphate-buffered saline (PBS; containing $137 \mathrm{mM} \mathrm{NaCl}, 2.7 \mathrm{mM}$ $\left.\mathrm{KCl}, 10 \mathrm{mM} \mathrm{Na} \mathrm{HPO}_{4}, 1.8 \mathrm{mM} \mathrm{K \textrm {K } _ { 2 }} \mathrm{PO}_{4}, \mathrm{pH} 7.4\right)$, and permeabilized in $0.25 \%$ Triton X-100 (Sigma-Aldrich, St. Louis, http://www. sigmaaldrich.com) for 30 minutes at room temperature. Thereafter, SVZ cultures were incubated for 20 minutes in $3 \% \mathrm{H}_{2} \mathrm{O}_{2}$ and reacted for terminal transferase $(0.25 \mathrm{U} / \mu \mathrm{l})$ biotinylated dUTP $(6$ $\mu \mathrm{M})$ nick-end labeling of fragmented DNA in TdT buffer ( $\mathrm{pH} 7.5)$ (all from Roche, Basel, Switzerland, http://www.roche-appliedscience.com) for 1 hour 30 minutes at $37^{\circ} \mathrm{C}$ in a humidified chamber. The enzymatic reaction was stopped by 15 minutes of incubation in $300 \mathrm{mM} \mathrm{NaCl}$ (Sigma-Aldrich) and $30 \mathrm{mM}$ sodium citrate (Sigma-Aldrich) buffer. Following an additional rinse in PBS, cultures were incubated for 30 minutes at room temperature with the avidin-biotin-peroxidase complex (1:100; Vector Laboratories, Burlingame, CA, http://www.vectorlabs.com). Peroxidase activity was revealed by the $3,3^{\prime}$-diaminobenzidine chromogen $(0.025 \%$; SigmaAldrich) intensified with $0.08 \% \mathrm{NiCl}_{2}$ in $30 \mathrm{mM}$ Tris- $\mathrm{HCl}$ (pH 7.6) buffer containing $0.003 \% \mathrm{H}_{2} \mathrm{O}_{2}$. The cell preparations were then dehydrated in ethanol (70\%, 2 minutes; $80 \%, 2$ minutes; $90 \%, 2$ minutes; 95\%, 2 minutes; 100\%, 2 minutes), cleared in xylene (3 minutes), and mounted using DEPEX mounting medium (SigmaAldrich). Photomicrographs of TUNEL were recorded using a digital camera (Axiocam HRC; Carl Zeiss, Göttingen, Germany, http://www.zeiss.com) adapted to an Axioskop 2 Plus fluorescent microscope (Carl Zeiss).

\section{Cell Proliferation Studies}

To investigate the effect of TNF- $\alpha$ on cell proliferation, SVZ cells were exposed to $10 \mu \mathrm{M}$ 5-bromo-2'-deoxyuridine (BrdU) (SigmaAldrich) for the last 4 hours of each TNF- $\alpha$ treatment (48 hours or 7 days). Then, SVZ cells were fixed in 4\% PFA for 30 minutes and rinsed for 30 minutes in $0.15 \mathrm{M} \mathrm{PBS}$, at room temperature. BrdU was then unmasked following successive passages in $1 \%$ Triton $\mathrm{X}-100$ for 30 minutes at room temperature, ice-cold $0.1 \mathrm{M} \mathrm{HCl}$ for 20 minutes, and finally $2 \mathrm{M} \mathrm{HCl}$ for 40 minutes at $40^{\circ} \mathrm{C}$. Following neutralization in sodium borate buffer $\left(0.1 \mathrm{M} \mathrm{Na}_{2} \mathrm{~B}_{4} \mathrm{O}_{7} \cdot 10 \mathrm{H}_{2} \mathrm{O}\right.$, pH 8.5; Sigma-Aldrich) for 15 minutes at room temperature, slices were 
rinsed in PBS, and nonspecific binding sites were blocked with 3\% bovine serum albumin (BSA; Sigma-Aldrich) and $0.3 \%$ Triton $\mathrm{X}-100$ in PBS for 30 minutes at room temperature. SVZ cultures were then incubated overnight at $4{ }^{\circ} \mathrm{C}$ with the primary rat monoclonal anti-BrdU antibody (1:50; Oxford Biotechnology, Raleigh, NC) in PBS containing $0.1 \%$ Triton X-100 and $0.3 \%$ BSA. After a rinse in PBS, SVZ cultures were incubated with a secondary anti-rat IgG labeled with Alexa Fluor 594 (1:200; Molecular Probes, Eugene, OR, http://probes.invitrogen.com) for 1 hour at room temperature. After an additional rinse in PBS, SVZ cell nuclei were stained with Hoechst 33342 (Molecular Probes) ( $2 \mu \mathrm{g} / \mathrm{ml}$ in PBS containing $0.25 \% \mathrm{BSA}$ ) for 5 minutes at room temperature. Finally, the preparations were mounted using DakoCytomation fluorescent medium (DakoCytomation, Carpinteria, CA, http://www.dakocytomation. com). Fluorescent images were recorded using a confocal microscope (LSM 510 Meta; Carl Zeiss) or an Axioskop 2 Plus fluorescent microscope (Carl Zeiss).

\section{Immunocytochemical Staining for Phenotype Discrimination and Cell Signaling}

After fixation in 4\% PFA for 30 minutes at room temperature, SVZ cells were permeabilized, and nonspecific binding sites were blocked with $0.25 \%$ Triton X-100 and 3\% BSA dissolved in $0.15 \mathrm{M}$ PBS for 30 minutes at room temperature. SVZ cells were subsequently incubated overnight at $4^{\circ} \mathrm{C}$ with the following primary antibodies, all of which had been prepared in PBS containing $0.1 \%$ Triton X-100 and 0.3\% BSA: mouse monoclonal anti-MAP-2 (1: 200; Sigma-Aldrich), mouse monoclonal anti-NeuN (1:100; Chemicon, Temecula, CA, http://www.chemicon.com), mouse monoclonal anti-TNFR1 (1:100; R\&D Systems), mouse monoclonal anti-TNFR2 (1:100; R\&D Systems), rabbit polyclonal antiphospho-(Thr183/Tyr185)-SAPK/JNK (1:100; Cell Signaling Technology, Danvers, MA, http://www.cellsignal.com), or mouse monoclonal anti- $\tau$ ( $\tau$ 46) (1:800; Cell Signaling Technology). Thereafter, the coverslips were rinsed in PBS and incubated for 1 hour at room temperature with the appropriate secondary antibodies: anti-rabbit IgG labeled with Alexa Fluor 488 (1:200) or with Alexa Fluor 594 (1:200) or anti-mouse IgG labeled with Alexa Fluor 594 (1:200) (all from Molecular Probes). After an additional rinse in PBS, SVZ cell nuclei were stained with Hoechst 33342 (2 $\mu \mathrm{g} / \mathrm{ml}$ in PBS containing $0.25 \%$ BSA) for 5 minutes at room temperature. Finally, the preparations were mounted using DakoCytomation fluorescent medium. Fluorescent images were recorded using a confocal microscope (LSM 510 Meta; Carl Zeiss) or an Axioskop 2 Plus fluorescent microscope (Carl Zeiss).

\section{Single-Cell Calcium Imaging}

To determine the functional differentiation pattern of SVZ cells, we analyzed the variations of intracellular calcium-free levels $\left(\left[\mathrm{Ca}^{2+}\right]_{\mathrm{i}}\right)$ in single cells following stimulation with $50 \mathrm{mM} \mathrm{KCl}$ or $100 \mu \mathrm{M}$ histamine (Sigma-Aldrich) [38]. KCl depolarization causes an increase in $\left[\mathrm{Ca}^{2+}\right]_{i}$ in neurons [39], whereas stimulation with histamine leads to an increase in $\left[\mathrm{Ca}^{2+}\right]_{\mathrm{i}}$ in stem/progenitor cells [40].

SVZ cultures were loaded for 40 minutes with $5 \mu \mathrm{M}$ Fura2/AM (Molecular Probes), $0.1 \%$ fatty acid-free BSA, and $0.02 \%$ pluronic acid F-127 (Molecular Probes) in Krebs solution (132 mM $\mathrm{NaCl}, 4 \mathrm{mM} \mathrm{KCl}, 1.4 \mathrm{mM} \mathrm{MgCl}_{2}, 1 \mathrm{mM} \mathrm{CaCl}_{2}, 6 \mathrm{mM}$ glucose, 10 $\mathrm{mM}$ HEPES, $\mathrm{pH} 7.4$ ), in an incubator with $5 \% \mathrm{CO}_{2}$ and $95 \%$ atmospheric air at $37^{\circ} \mathrm{C}$. After a 10 -minute postloading period at room temperature in the same medium without Fura- 2 and pluronic acid, to obtain a complete hydrolysis of the probe, the glass coverslip was mounted on an RC-20 chamber in a PH3 platform (Warner Instruments, Hamden, CT, http://www.warneronline.com) on the stage of an inverted fluorescence microscope (Axiovert 200; Carl Zeiss). Cells were continuously perfused with Krebs solution and stimulated by applying high-potassium Krebs solution (containing $50 \mathrm{mM} \mathrm{KCl}$, isosmotic substitution with $\mathrm{NaCl}$ ) or $100 \mu \mathrm{M}$ histamine. Solutions were added to the cells by a fast-pressurized $(95 \%$ air, $5 \% \mathrm{CO}_{2}$ atmosphere) system (AutoMate Scientific, Inc., Berkeley, CA, http://www.autom8.com). The variations of $\left[\mathrm{Ca}^{2+}\right]_{\mathrm{i}}$ were evaluated by quantifying the ratio of the fluorescence emitted at 510 $\mathrm{nm}$ following alternate excitation (750 milliseconds) at 340 and 380 $\mathrm{nm}$, using a Lambda DG4 apparatus (Sutter Instrument, Novato,
CA, http://www.sutter.com) and a $510 \mathrm{~nm}$ band-pass filter (Carl Zeiss) before fluorescence acquisition with a $\times 40$ objective and a CoolSNAP digital camera (Roper Scientific, Trenton, NJ, http:// www.roperscientific.com). Acquired values were processed using the MetaFluor software (Universal Imaging Corp., West Chester, PA, http://www.moleculardevices.com). Histamine/ $\mathrm{KCl}$ values for Fura-2 ratio were calculated to determine the extent of neuronal maturation in cultures.

\section{Isolation of Total RNA from SVZ Cells}

Total RNA was isolated from SVZ cells and murine spleen cells, using TRI Reagent (Sigma-Aldrich) according to the manufacturer's instructions. Cells were gently homogenized in guanidium thiocyanate and phenol and allowed to stand at room temperature to secure the complete dissociation of nucleoprotein complexes. Chloroform was added, allowing a clear isolation of RNA in the resultant aqueous phase. Then, the RNA was precipitated with isopropanol and the pellet was washed with $75 \%$ ( $\mathrm{vol} / \mathrm{vol})$ ethanol, redissolved in diethylpyrocarbonate-treated water, and stored at $-80^{\circ} \mathrm{C}$.

The total amount of RNA was quantified by optical density (OD) measurements at $260 \mathrm{~nm}$, and the purity was evaluated by measuring the ratio of OD at 260 and $280 \mathrm{~nm}$ (RNA/DNA calculator GeneQuant II; Amersham, Uppsala, Sweden, http://www. amersham.com). In addition, RNA quality was assessed by gel electrophoresis.

\section{Reverse Transcription-Polymerase Chain Reaction Analysis}

mRNA expression of TNFR1 and TNFR2 was determined by reverse transcription (RT)-polymerase chain reaction (PCR). First, cDNA was obtained from the transcription of $2 \mu \mathrm{g}$ of RNA using avian microblastosis virus reverse transcriptase and oligo-p(dT) 15 primers (Roche Molecular Biochemicals, Indianapolis, http://www. roche-applied-science.com). PCR was performed in a $50-\mu \mathrm{l}$ reaction system (Roche Molecular Biochemicals) containing $5 \mu \mathrm{l}$ of template cDNA, $1 \mu \mathrm{l}$ of deoxynucleotide mix, $5 \mu \mathrm{l}$ of $10 \times$ PCR buffer, $0.2 \mu \mathrm{l}$ of upstream primer, $0.2 \mu \mathrm{l}$ of downstream primer, a variable volume of water, and $0.25 \mu \mathrm{l}$ of DNA-free sensitive Taq DNA polymerase $\left(35\right.$ cycles of $95^{\circ} \mathrm{C}$ for 30 seconds, $53^{\circ} \mathrm{C} / 58^{\circ} \mathrm{C}$ [TNFR1/TNFR2] for 30 seconds, and $72^{\circ} \mathrm{C}$ for 30 seconds; Bioron $\mathrm{GmbH}$, Ludwigshafen, Germany, http://www.bioron.net). Primers used in PCRs were as follows: TNF- $\alpha$ receptor 1 , forward primer, $5^{\prime}$-CCG GGC CAC CTG GTC CG-3', and reverse primer, $5^{\prime}$-CAA GTA GGT TCC TTT GTG-3'; TNF- $\alpha$ receptor 2 , forward primer, 5'-CTC GCG CTG TTC GAA CTG-3', and reverse primer, 5'-GGT ATA CAT GCT TGC CTC ACA GTC-3' (MWG Biotech, Ebersberg, Germany, http://www.mwg-biotech.com) [26]; and $\beta$-actin, forward primer, 5'-GAC TAC CTC ATG AAG ATC CT-3', and reverse primer, $5^{\prime}$-ATC TTG ATC ATG GTG CTG- $3^{\prime}$ ( 35 cycles of $95^{\circ} \mathrm{C}$ for 60 seconds, $55^{\circ} \mathrm{C}$ for 60 seconds, and $72^{\circ} \mathrm{C}$ for 60 seconds).

PCR products of each sample were subjected to electrophoresis in a $1.5 \%$ agarose gel and stained with ethidium bromide. Negative controls were performed without RNA sample, which was replaced by water. Positive controls were total murine spleen mRNA samples. Photographs were taken in a Versa-Doc Imaging System (model 3000; Bio-Rad, Hercules, CA, http://www.bio-rad.com).

\section{Statistical Analysis}

In all experiments, measurements were performed in the border of SVZ neurospheres where migrating cells form a cell monolayer. For SCCI experiments, the percentage of neuronal-like responding cells (with a histamine/KCl ratio below 0.8 ) was calculated on the basis of one microscopic field per coverslip, containing approximately 100 cells (magnification, $\times 40$ ). Percentages of neuronal-like responding cells in untreated control cultures were set to $100 \%$. Each experimental condition was assayed in three different coverslips. Except where otherwise specified, the experiments were replicated in three independent culture preparations. Percentages of NeuN, BrdU, or TUNEL immunoreactive cells in SVZ cell cultures were calculated from cell counts in five independent microscopic fields in 
each coverslip with a $\times 40$ objective (approximately 200 cells per field). Quantification of P-SAPK/JNK positive nuclei per neurosphere (at 15 minutes) was done in two independent culture preparations in at least 20 nonoverlapping fields, using confocal digital images (magnification, $\times 40$; LSM 510 Meta; Carl Zeiss). Quantification of the number of neuritic ramifications positive for $\mathrm{P}$ SAPK/JNK per neurosphere, as well as the total neuritic length and growth cone-like structures per neurosphere (at 6 hours), was performed in five independent culture preparations in approximately 20 nonoverlapping fields per coverslip using digital images (magnification, $\times 20$ ). Software used was Axiovision, release 4.6 (Carl Zeiss).

Data are expressed as means \pm SE of mean (SEM). Statistical significance was determined by using the unpaired two-tailed Student's $t$ test, with $p<.05$ considered to represent statistical significance.

\section{RESULTS}

\section{SVZ Cells Express Both TNFR1 and TNFR2}

To investigate the expression of both TNFR1 and TNFR2, we performed RT-PCR [26] and immunocytochemistry in SVZ cultures. As shown in Figure 1, both receptors were detected by RT-PCR analysis ( $n=3$ for each receptor) (Fig. 1A) and by standard immunocytochemistry in differentiated and undifferentiated SVZ cells (Fig. 1C, 1D, respectively). Positive and negative controls were performed to confirm the specificity of the primers and of the primary antibodies used for the detection of both TNF- $\alpha$ receptors. In accordance with the higher levels of TNFR1 compared with TNFR2 detected by either RT-PCR and immunocytochemistry, clear Western blotting bands corresponding to the expression of TNFR1 were detected in SVZ explants and neurospheres (Fig. 1B).

\section{TNF- $\alpha$ Induces Neuronal Differentiation Via TNFR1 Activation}

To functionally evaluate neuronal differentiation in SVZ cultures, we established a method based on variations of $\left[\mathrm{Ca}^{2+}\right]_{\mathrm{i}}$ in single cells in response to $\mathrm{KCl}$ or histamine (Fig. 2B-2D) [38]. Membrane depolarization of neuronal cells following exposure to high $\mathrm{KCl}$ concentrations leads to the opening of voltage sensitive calcium channels and massive influx of calcium into the cytoplasm [39], whereas stimulation with histamine specifically triggers an increase in $\left[\mathrm{Ca}^{2+}\right]_{i}$ in immature $\mathrm{SVZ}$ cells [40]. In view of these findings, we demonstrated that the ratio of responses due to histamine or $\mathrm{KCl}$ exposure (Hist/KCl) differs significantly between cell type groups, with a low Hist $/ \mathrm{KCl}$ ratio (below 0.8) being characteristic of SVZ-derived neurons (Fig. 2C, 2D) [38].

Thus, to investigate whether TNF- $\alpha$ might influence the capacity of SVZ cells to differentiate into functional neuronal cells, 6-8-day-old SVZ neurospheres were allowed to develop on poly-D-lysine-coated coverslips for 7 days in the presence of recombinant mouse (1 or $10 \mathrm{ng} / \mathrm{ml}$ ) or human $(1 \mathrm{ng} / \mathrm{ml})$ TNF- $\alpha$. Adherence on a poly-D-lysine substrate and withdrawal of growth factors are necessary steps to promote outward cell migration and differentiation of progenitor cells at the border of the neurospheres [41]. At the border of neurospheres, migrating cells emerged, forming a cell monolayer, where all the measurements of $\left[\mathrm{Ca}^{2+}\right]_{\mathrm{i}}$ and cell countings of immunostainings were performed. At the end of TNF- $\alpha$ treatments, the SVZ cells were loaded with the Fura-2/AM calcium probe, perfused continuously for 15 minutes with Krebs solution, and briefly (2 minutes) stimulated with $50 \mathrm{mM} \mathrm{KCl}$ or $100 \mu \mathrm{M}$ histamine, as depicted in Figure 2B.



Figure 1. SVZ cells express both TNFR1 and TNFR2. (A): reverse transcription-polymerase chain reaction detection of mRNA for TNFR1 and TNFR2 in SVZ neurospheres. Left lane is a DNA ladder to indicate size of amplified products (TNFR1, approximately 300 base pairs [bp]; TNFR2, approximately $233 \mathrm{bp}$ ). Positive controls $(+)$ were done in total murine spleen mRNA. (B): Detection of TNFR1 protein by Western blotting in hippocampus, SVZ tissues, and SVZ neurospheres. AntiTNFR1 antibody was purchased from Santa Cruz Biotechnology Inc. (Santa Cruz, CA, http://www.scbt.com) and diluted at 1:200. (C, D): Representative fluorescent confocal photomicrographs depicting TNFR1 and TNFR2 immunoreactivity (red staining for both receptors) in SVZ cells migrating out of a neurosphere 2 days after plating (C) and in mechanically dissociated cells from SVZ neurospheres, plated 1 hour before fixation (D). Hoechst 33342 staining (blue) was used to visualize cell nuclei. Scale bars $=10 \mu \mathrm{m}$. Abbreviations: SVZ, subventricular zone; TNFR, tumor necrosis factor receptor.

Interestingly, the majority of TNF-treated SVZ cells displayed an increase in the $\left[\mathrm{Ca}^{2+}\right]_{\mathrm{i}}$ in response to $\mathrm{KCl}$ but not to histamine stimulation, consistent with a neuronal-like profile (Fig. 3A). In contrast, control, nontreated cultures showed a predominant immature-like profile, characterized by an increase in $\left[\mathrm{Ca}^{2+}\right]_{\mathrm{i}}$ in response to histamine but a small response or no response to $\mathrm{KCl}$ stimulation (Fig. 3A). Quantification of the percentage of cells displaying a low histamine $/ \mathrm{KCl}$ ratio showed that TNF- $\alpha$ induced increases of approximately threefold $(308.9 \% \pm 46.52 \%$; 928 cells analyzed; $p<.001)$ and approximately twofold $(203.5 \% \pm 38.9 \% ; 325$ cells analyzed; $p<.05)$ in the proportion of neuronal-like responding SVZ cells, for 1 and $10 \mathrm{ng} / \mathrm{ml}$, respectively, compared with control, nontreated cells $(1,930$ cells analyzed) (set to $100 \%)$ (Fig. 3A). To determine which receptor mediates the proneurogenic effect of TNF- $\alpha$, SVZ cells were coincubated for 7 days with $1 \mathrm{ng} / \mathrm{ml}$ TNF- $\alpha$ and with neutralizing antibodies to each TNF- $\alpha$ receptor. We found that the proneurogenic effect mediated by $1 \mathrm{ng} / \mathrm{ml}$ TNF- $\alpha$ was inhibited by coincubation with the neutralizing 
A

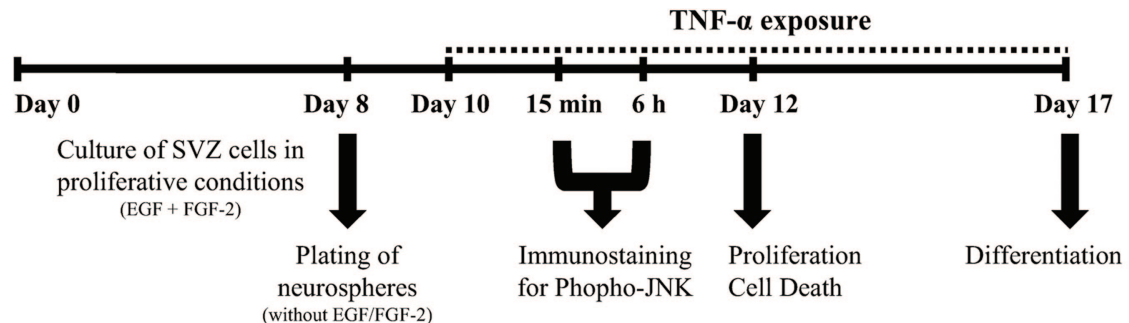

B

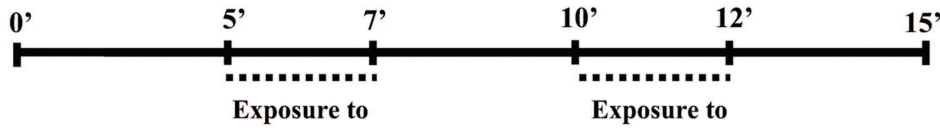

50 mM KCl

$100 \mu \mathrm{M}$ Histamine
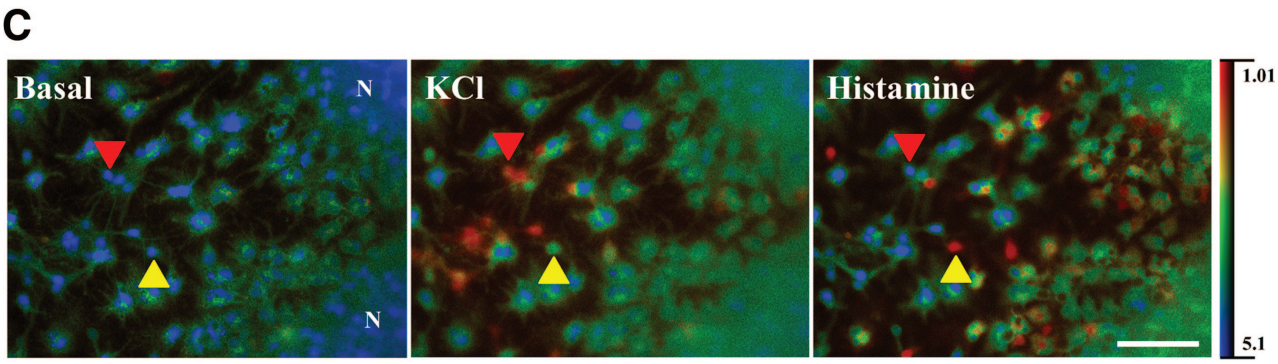

D

SVZ: Immature-like profiles

SVZ: Neuronal-like profiles

Cultured hippocampal neurons
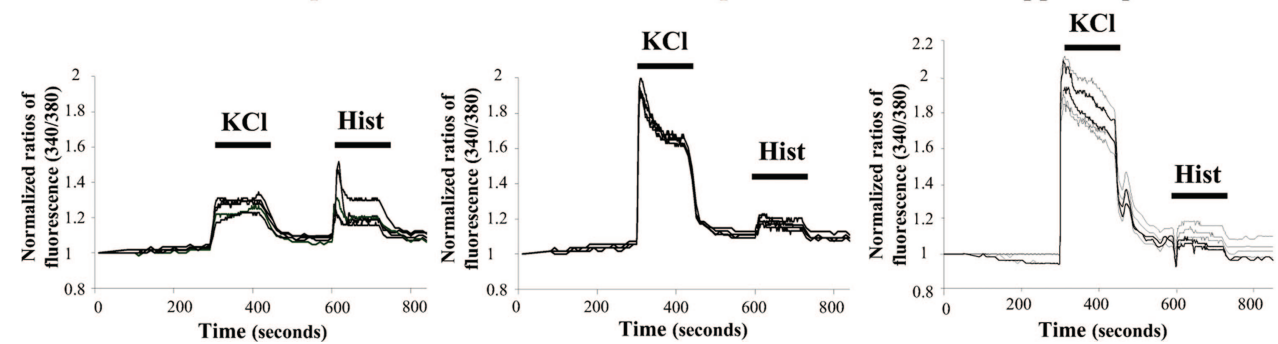

Figure 2. Experimental protocol for the functional evaluation of neuronal differentiation in mouse SVZ cell cultures. (A): Schematic representation of the protocol used for studying the effects of TNF- $\alpha$ on SVZ cell cultures. Dashed line, exposure to TNF- $\alpha$. (B): SVZ cultures were perfused continuously in Krebs solution for $15 \mathrm{~min}$ and stimulated for $2 \mathrm{~min}$ (from $\mathrm{min} 5$ to $\mathrm{min} 7$ ) with $50 \mathrm{mM} \mathrm{KCl}$ and for $2 \mathrm{~min}$ (from $\mathrm{min} 10$ to $\mathrm{min} 12$ ) with $100 \mu \mathrm{M}$ Hist. (C): Pseudocolor images of a single-cell calcium imaging experiment obtained by ratio of fluorescence emitted at $510 \mathrm{~nm}$ following excitation at 340 or $380 \mathrm{~nm}$. Images were taken from the same field and obtained at different time points, upon $\mathrm{Krebs}$ solution (basal), $\mathrm{KCl}$, and Hist perfusion. Neurons increased $\left[\mathrm{Ca}^{2+}\right]_{\mathrm{i}}$ following $\mathrm{KCl}$ (red arrowhead), and immature cells increased $\left[\mathrm{Ca}^{2+}\right]_{\mathrm{i}}$ following Hist perfusion (yellow arrowhead). Scale of non-normalized ratio of fluorescence intensity is indicated at the right; blue and red indicate low and high ratios, respectively. Observed fields contained approximately 100 cells. Scale bar $=50 \mu \mathrm{m}$. (D): Profiles of five representative cells presenting an immature-like response (left graph) or a neuronal-like response (middle graph) in SVZ culture and in a culture of hippocampal neurons as a positive control to show neuronal profile of responses (right graph). Additional details are given in Agasse et al. [38]. Abbreviations: h, hours; Hist, histamine; min, minutes; N, neurosphere; SVZ, subventricular zone; TNF- $\alpha$, tumor necrosis factor $\alpha$.

anti-TNFR1 antibody $(54.8 \% \pm 34.2 \% ; 288$ cells analyzed; $p<$ .001 vs. $1 \mathrm{ng} / \mathrm{ml}$ TNF alone) but not with the neutralizing anti-TNFR2 antibody $(368.8 \% \pm 84.3 \% ; 224$ cells analyzed) (Fig. 3A). In agreement, SVZ cultures incubated with human recombinant TNF- $\alpha$ (1 ng/ml), known to bind to mouse TNFR1 only [42], showed an approximately threefold increase $(323.2 \% \pm 83.2 \% ; 650$ cells analyzed) in the proportion of neuronal-like responding cells, similarly to mouse recombinant TNF- $\alpha$ (Fig. 3A). To disclose a possible effect of endogenous secreted TNF- $\alpha$ on SVZ cell differentiation, the cells were treated with an anti-TNF- $\alpha$ antibody. Neutralization of endogenous TNF- $\alpha$ did not significantly reduce the percentage of neuronal-like cells in the culture (control: $100.0 \% \pm 15.5 \%, n=7$ coverslips, 528 cells analyzed; anti-TNF- $\alpha$ antibody alone: $92.9 \% \pm 35.9 \%, n=4$ coverslips, 306 cells analyzed; $p=.84$ ). Moreover, mouse recombinant TNF- $\alpha$ induced increases in NeuN-immunoreactive cells (a neuronal-specific nuclear protein present on mature neurons) to $26 \%(26.4 \% \pm 1.9 \% ; 2,809$ cells counted; $p<$ $.001)$ and $22 \%(22.3 \% \pm 3.1 \% ; 4,057$ cells counted; $p<$ .001 ) for 1 and $10 \mathrm{ng} / \mathrm{ml}$, respectively, compared with $8 \%$ NeuN-immunoreactive cells present in control cultures $(8.5 \% \pm$ $1.0 \%$; in 8,446 cells counted). Interestingly, no significant effect was observed in SVZ cells treated with 0.3 or 100 $\mathrm{ng} / \mathrm{ml}$ TNF- $\alpha$ (Fig. 3B). Immunoreactivity against MAP-2, a microtubule-associated protein present in dendrites of mature neurons, was also increased in SVZ cell cultures treated with both 1 and $10 \mathrm{ng} / \mathrm{ml}$ mouse recombinant TNF- $\alpha$, compared with the control (Fig. 3C). TNF- $\alpha$ treatment had no effect on the capacity of the cells to differentiate into the glial lineage, as determined by immunostaining for glial fibrillary acidic protein (data not shown). Together, these results show that when exogenously added at 1 and $10 \mathrm{ng} / \mathrm{ml}$, TNF- $\alpha$ induces neuronal differentiation in SVZ cells via TNFR1 activation. 
A

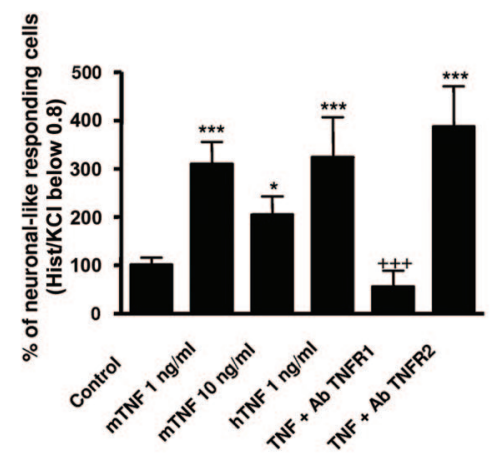

B

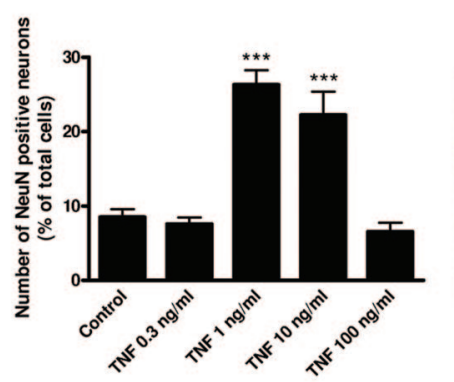

C



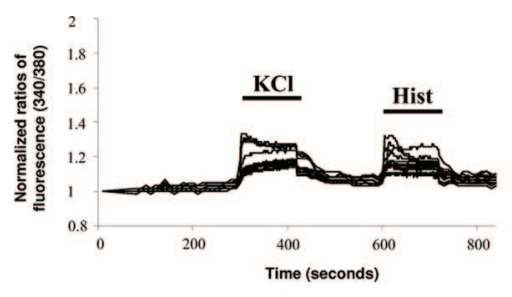

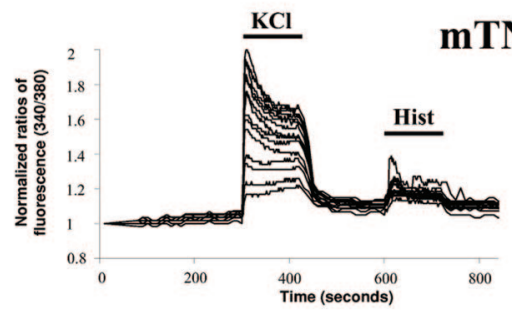

mTNF $1 \mathrm{ng} / \mathrm{ml}$

TNF $10 \mathrm{ng} / \mathrm{ml}$
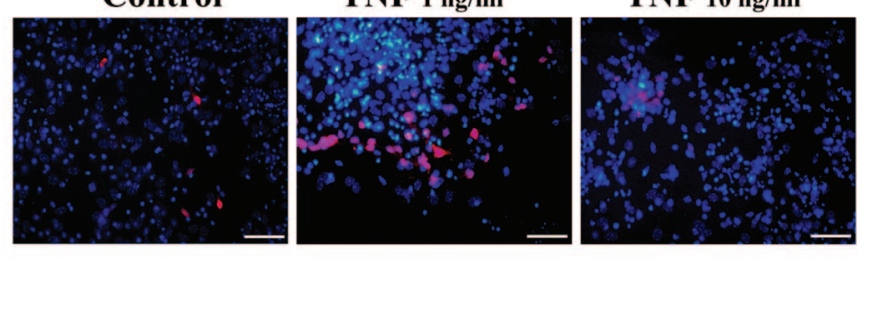

TNF $1 \mathrm{ng} / \mathrm{ml}$

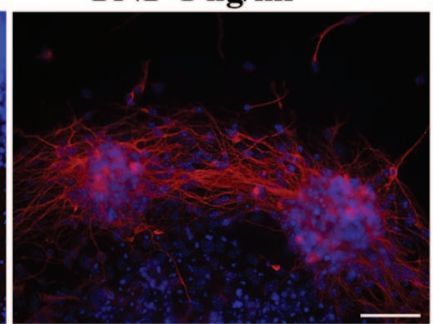

Figure 3. TNF induces neuronal differentiation in mouse subventricular zone (SVZ) cell cultures via TNFR1 activation. (A): Bar graph depicts the percentages of neuronal-like responding cells in SVZ control cultures (no drug exposure) and in cultures exposed to $1 \mathrm{or} 10 \mathrm{ng} / \mathrm{ml} \mathrm{mTNF}$ or to $1 \mathrm{ng} / \mathrm{ml}$ hTNF for 7 days. In another set of experiments, SVZ cells were coincubated with $1 \mathrm{ng} / \mathrm{ml}$ mouse TNF and blocking Abs to TNFR1 (TNF + Ab TNFR1) or TNFR2 (TNF + Ab TNFR2). Data are expressed as a mean \pm SEM $(n=5-26) . *, p<.05 ; * * *, p<.001$ using the unpaired Student's $t$ test for comparison with SVZ control cultures (set to $100 \%$ );,$+++ p<.001$ using the unpaired Student's $t$ test for comparison with $1 \mathrm{ng} / \mathrm{ml} \mathrm{mTNF}$. Shown are representative single-cell calcium imaging profiles of response of 15 cells in a control culture and in a culture treated with $1 \mathrm{ng} / \mathrm{ml} \mathrm{mTNF}$. (B): Bar graph depicts the percentages of NeuN-positive cells, expressed as percentage of the total number of cells per culture, in control cultures and in cultures treated with mouse TNF for 7 days. Data are expressed as a mean \pm SEM $(n=4-13)$. ***, $p<.001$ using the unpaired Student's $t$ test for comparison with SVZ control cultures. Representative fluorescent photomicrographs of NeuN-positive neurons (red nuclei) and Hoechst 33342 staining (blue nuclei) in SVZ cultures. Scale bars $=50 \mu \mathrm{m}$. (C): Representative fluorescent photomicrographs of MAP-2-positive neurons (red staining) and Hoechst 33342 staining (blue nuclei) in a control culture and in cultures exposed to 1 or $10 \mathrm{ng} / \mathrm{ml}$ TNF for 7 days. Scale bars $=50 \mu \mathrm{m}$. Abbreviations: Ab, antibody; Hist, histamine; hTNF, human tumor necrosis factor $\alpha$; mTNF, mouse tumor necrosis factor $\alpha$; NeuN, neuronal nuclear protein; TNF, tumor necrosis factor $\alpha$; TNFR, tumor necrosis factor receptor.

\section{TNF- $\alpha$ Modulates Both Cell Proliferation and Survival}

To investigate the role of $\mathrm{TNF}-\alpha$ on cell proliferation and survival, SVZ cell cultures were exposed to TNF- $\alpha$ for 48 hours or 7 days, and BrdU and TUNEL staining was performed (Fig. 2A). SVZ cells exposed for 48 hours to $1 \mathrm{ng} / \mathrm{ml}$ but not to 10 $\mathrm{ng} / \mathrm{ml}$ TNF- $\alpha$ displayed an approximately 1.5 -fold increase $(6.3 \% \pm 0.6 \% ; n=6$ coverslips; 3,987 cells counted; $p<.05)$ in the percentage of BrdU-positive cells compared with control cultures $(4.1 \% \pm 0.6 \% ; n=6$ coverslips; 4,370 cells counted $)$ (Fig. 4A). No significant effect on cell proliferation was observed in 0.3 and $100 \mathrm{ng} / \mathrm{ml} \mathrm{TNF-} \alpha$-treated cells (data not shown). Since the cells were grown under differentiation conditions [41], the proliferative effect mediated by exposure to 1 $\mathrm{ng} / \mathrm{ml}$ TNF- $\alpha$ for 48 hours was not observed following 7 days of incubation (control: $2.3 \% \pm 0.08 \% ; n=3$ coverslips, TNF- $\alpha$ : $1.9 \% \pm 0.3 \% ; n=6$ coverslips, $p>.05$ ), probably because of a shift from cell proliferation to neuronal differentiation (described below).

Moreover, we also performed TUNEL staining to examine the effects of TNF- $\alpha$ on cell apoptosis. Exposure of SVZ cells to 10 and $100 \mathrm{ng} / \mathrm{ml} \mathrm{TNF-} \alpha$ for 48 hours significantly increased the percentage of TUNEL-positive apoptotic cells to $21 \%$ $(21.1 \% \pm 1.6 \% ; n=12$ coverslips; 6,511 cells counted; $p<$ $.001)$ and to $25 \%(25.7 \% \pm 2.9 \% ; n=8$ coverslips; 4,852 cells counted; $p<.001)$, compared with $13 \%$ of apoptotic cells in the control cultures $(13.1 \% \pm 1.1 \% ; n=13$ coverslips; 7,909 cells counted) (Fig. 4B). No significant effect on cell death was 
A

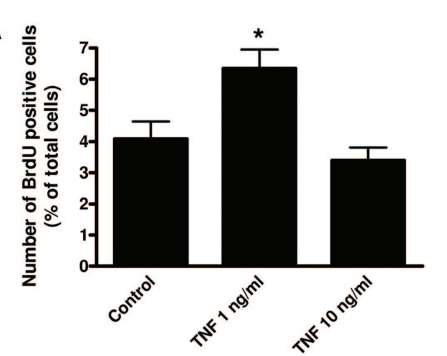

B

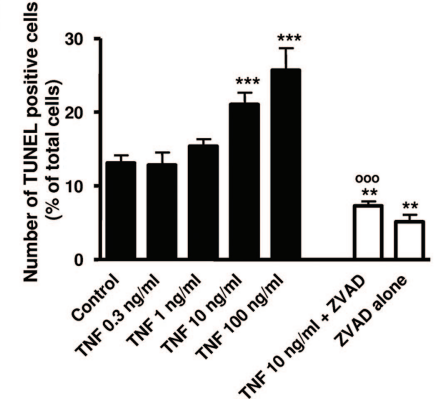

Figure 4. TNF differentially modulates cell proliferation and survival in mouse subventricular zone (SVZ) cell cultures. (A): Bar graph depicts the number of BrdU-positive cells, expressed as percentage of the total number of nuclei per culture, in control cultures and in cultures exposed to 1 or $10 \mathrm{ng} / \mathrm{ml}$ TNF for 48 hours. Data are expressed as a mean $\pm \operatorname{SEM}(n=3-6)$. Shown is a representative fluorescent confocal photomicrograph of BrdU (red nuclei) and Hoechst 33342 staining (blue nuclei) in a control culture. Scale bar $=20 \mu \mathrm{m}$. (B): Bar graph depicts the number of TUNEL-positive nuclei, expressed as percentage of the total number of nuclei, in control cultures and in cultures exposed to TNF for 48 hours. Data are expressed as a mean \pm SEM $(n=4-13)$. Shown is a representative transmission photomicrograph of TUNEL staining (black nucleus) in a control culture. Scale bar $=50 \mu \mathrm{m} . *, p<$ $.05 ; * *, p<.01 ; * * *, p<.001$ using the unpaired Student's $t$ test for comparison with SVZ control cultures; $000, p<.001$ using the unpaired Student's $t$ test for comparison with $10 \mathrm{ng} / \mathrm{ml} \mathrm{TNF}$ alone. Abbreviations: BrdU, 5-bromo-2'-deoxyuridine; TNF, tumor necrosis factor $\alpha$; TUNEL, terminal deoxynucleotidyl transferase dUTP nick-end labeling; ZVAD, z-Val-Ala-DL-Asp (OMe)-fluoromethylketone.

observed in 0.3 and $1 \mathrm{ng} / \mathrm{ml}$ TNF-treated cells (Fig. 4B). To ascertain that the increase in TUNEL-positive nuclei is consistent with an induction of apoptosis due to the incubation with 10 $\mathrm{ng} / \mathrm{ml} \mathrm{TNF}-\alpha, \mathrm{SVZ}$ cells were coincubated with TNF- $\alpha$ and 25 $\mu \mathrm{M} z V A D-f m k$, a proapoptotic caspase inhibitor. As expected, zVAD-fmk alone inhibited the basal cell apoptosis inherent in control cultures $(5.1 \% \pm 0.9 \% ; n=3$ coverslips; 2,234 cells counted; $p<.01$ vs. control; the zVAD-fmk solution vehicle, dimethyl sulfoxide, was without effect). Moreover, the toxic effect mediated by $10 \mathrm{ng} / \mathrm{ml} \mathrm{TNF}-\alpha$ was inhibited when SVZ cells were coincubated with $25 \mu \mathrm{M} z \mathrm{ZAD}$-fmk $(7.2 \% \pm 0.6 \%$; $n=6$ coverslips; 4,193 cells counted; $p<.001$ vs. $10 \mathrm{ng} / \mathrm{ml}$ TNF alone and $p<.01$ vs. control) (Fig. 4B). Taken together, these results suggest that $1 \mathrm{ng} / \mathrm{ml} \mathrm{TNF}-\alpha$ induces cell proliferation, whereas at high concentrations (10 and $100 \mathrm{ng} / \mathrm{ml}) \mathrm{TNF}-\alpha$ triggers cell apoptosis.

\section{TNF- $\alpha$ Activates the SAPK/JNK Pathway in $\tau$-Positive Axons}

Several studies have shown that MAP kinase pathways, in particular the SAPK/JNK pathway, play a key role in the signaling transduction of TNF- $\alpha[43,44]$. To investigate whether the SAPK/ JNK signaling pathway was activated by TNF- $\alpha$, SVZ cell cultures were exposed to TNF- $\alpha$ for 15 minutes or 6 hours (Fig. 2A). At the end of each treatment, immunocytochemistry against the phosphorylated (activated) forms of the JNK kinase (i.e., P-SAPK/JNK) was performed using an antibody that specifically detects endogenous levels of p46 and p54 of the three JNK isoforms (i.e., JNK1, JNK2, and JNK3). Exposure of SVZ cell cultures to 1 or $10 \mathrm{ng} / \mathrm{ml} \mathrm{TNF-} \alpha$ for 15 minutes induced an increase in P-SAPK/JNK-positive nuclei per neurosphere $(1 \mathrm{ng} / \mathrm{ml} \mathrm{TNF}, 26.7 \pm 2.7, n=3$ coverslips, $p<$ $.001 ; 10 \mathrm{ng} / \mathrm{ml} \mathrm{TNF}, 33.2 \pm 4.7, n=2$ coverslips, $p<.05)$ compared with control cultures $(1.5 \pm 0.3 ; n=2$ coverslips) (Fig. $5 \mathrm{~A}$, top row). Interestingly, exposure of SVZ cells to 1 or $10 \mathrm{ng} / \mathrm{ml}$ TNF- $\alpha$ for 6 hours (but not for 15 minutes) induced a robust $\mathrm{P}-\mathrm{SAPK} / \mathrm{JNK}$ immunoreactivity in growth cone-like projections and in neurites emerging from the neurospheres and not in the nucleus (Fig. 5A, middle row). Control cultures showed a diffuse or faint P-SAPK/JNK staining throughout the cytoplasm, with only a few positive growth cone-like structures immunoreactive to $\mathrm{P}$ SAPK/JNK and little or no nuclear localization of P-SAPK/JNK (Fig. 5A, top and middle rows). Moreover, quantification of the number of ramifications per neurosphere, as well as the total length of ramifications and growth cone-like projections/neurites per neurosphere, showed that $1 \mathrm{ng} / \mathrm{ml} \mathrm{TNF}-\alpha$ induced an approximately fourfold increase in both parameters, compared with control, nontreated cultures (Fig. 5A, bar graphs). This effect was lost at 100 $\mathrm{ng} / \mathrm{ml}$ concentration. All the measurements were performed at the border of neurospheres, where the P-SAPK/JNK-immunoreactive fibers emerge. To investigate whether P-SAPK/JNK immunoreactivity was associated with axons, double immunocytochemistry against P-SAPK/JNK and $\tau$, a microtubule-associated protein that induces bundling and stabilization of axonal microtubules, was performed. As shown in Figure 5B, P-SAPK/JNK immunoreactivity, induced by exposure of SVZ cells to 1 and $10 \mathrm{ng} / \mathrm{ml} \mathrm{TNF}-\alpha$ for 6 hours, was localized in $\tau$-positive axons. Together, these data suggest that low concentrations $(1 \mathrm{ng} / \mathrm{ml})$ of TNF- $\alpha$ promote axonogenesis and neuronal maturation of SVZ cell cultures.

\section{DISCUSSION}

The major finding of the present work is that TNF- $\alpha$, specially at a concentration of $1 \mathrm{ng} / \mathrm{ml}$, induces neurogenesis in mouse SVZ cell cultures, suggesting that some inflammatory mediators may promote brain repair following injury. We observed that 1 and $10 \mathrm{ng} / \mathrm{ml}$ TNF- $\alpha$ induced an increase in the percentage of cells with a neuronal-like profile (Hist/ $\mathrm{KCl}$ below 0.8 ), thus responding more to $\mathrm{KCl}$ and less to histamine compared with the control, nontreated cultures. Moreover, TNF- $\alpha$ induced an increase in the percentage of NeuN-positive neurons, as well as the immunoreactivity to the neuronal marker MAP-2. Our data suggest that the proneurogenic effect mediated by TNF- $\alpha$ involves the activation of the TNFR1, since exposure of SVZ cells to human TNF- $\alpha$ induced an increase in the percentage of cells with a neuronal-like profile, similar to the percentage increase mediated by mouse recombinant TNF- $\alpha$ and neutralizing antibodies to TNFR1, but not TNFR2, inhibited the proneurogenic effect mediated by $1 \mathrm{ng} / \mathrm{ml}$ TNF- $\alpha$. Nevertheless, we cannot exclude a possible involvement of the TNFR2 in other effects, such as survival and proliferation. To date, studies on the effects of TNF- $\alpha$ on neural stem/progenitor cells have yielded conflicting results. Only a few reports have shown a proneurogenic effect mediated by TNF- $\alpha$, although this effect was associated with AIDS dementia and not directly with brain repair [33, 34]. Moreover, other members of the TNF receptors family, such as p75 and Fas, can be also involved in nonapoptotic pathways, such as neurite outgrowth and regeneration [45, 46].

Using a BrdU incorporation assay, our results provide evidence that TNF- $\alpha$ positively regulates proliferation in SVZ cells treated with $1 \mathrm{ng} / \mathrm{ml}$ but not those treated with $10 \mathrm{ng} / \mathrm{ml} \mathrm{TNF}-\alpha$. In line with our results, it was reported by others that endoge- 
A
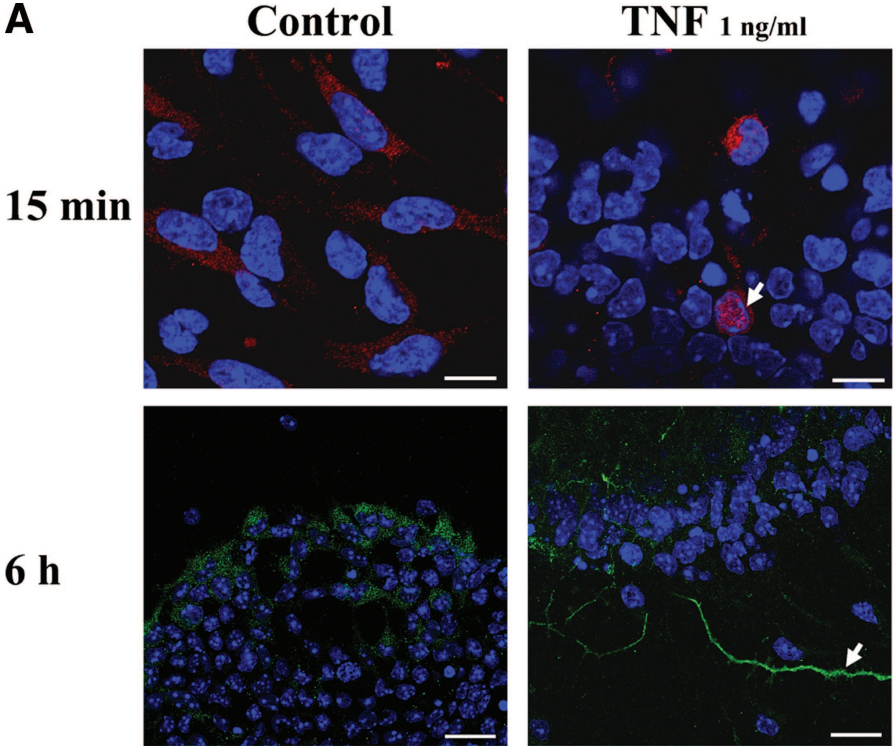

$6 \mathrm{~h}$
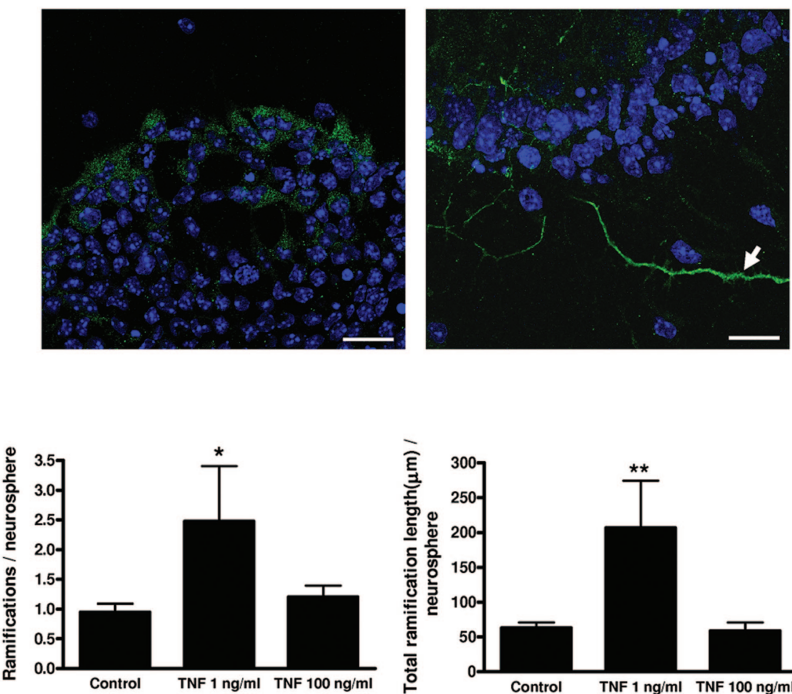

B
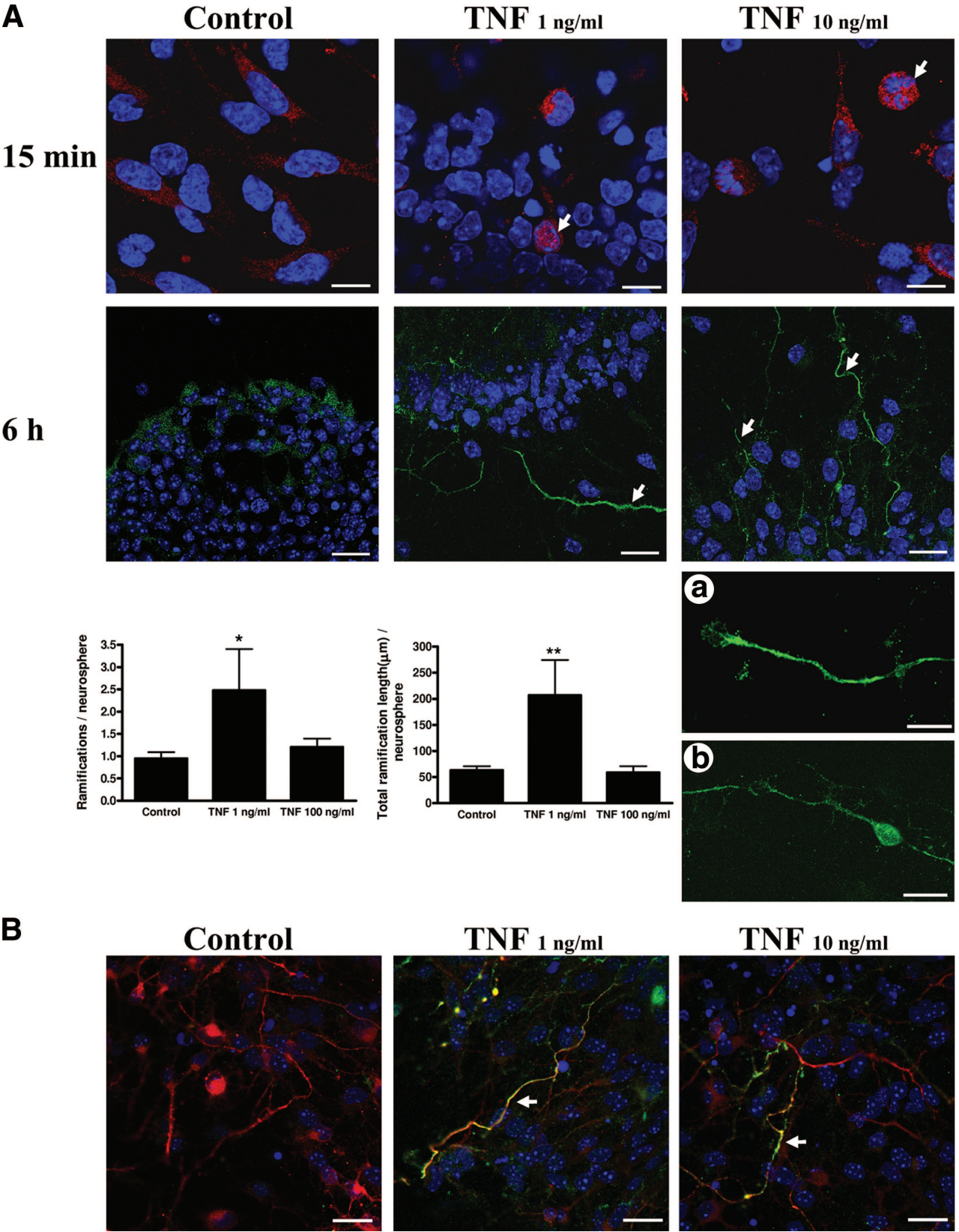

Figure 5. TNF induces activation of the c-Jun N-terminal kinase (JNK) MAPK pathway on growing axons. (A): Top row depicts representative fluorescent confocal photomicrographs of the P-SAPK/JNK (red) and Hoechst 33342 staining (blue nuclei) in control cultures and in cultures exposed to 1 or $10 \mathrm{ng} / \mathrm{ml}$ TNF for $15 \mathrm{~min}$. Scale bars $=10 \mu \mathrm{m}$. Arrows depict P-SAPK/JNK immunoreactivity in the nucleus. Middle row depicts representative fluorescent confocal photomicrographs of the P-SAPK/JNK (green) and Hoechst 33342 staining (blue nuclei) in control cultures and in cultures exposed to $1 \mathrm{or} 10 \mathrm{ng} / \mathrm{ml} \mathrm{TNF}$, for $6 \mathrm{~h}$. Scale bars $=20 \mu \mathrm{m}$. Arrows depict P-SAPK/JNK immunoreactivity in growth cone-like structures and in neurites. (Aa, Ab): High-magnification fluorescent confocal photomicrographs of a growth cone-like structure (Aa) and a positive cell (Ab) to the P-SAPK/JNK staining in subventricular zone (SVZ) cultures treated with $10 \mathrm{ng} / \mathrm{ml} \mathrm{TNF}$ for $6 \mathrm{~h}$. Scale bars $=10 \mu \mathrm{m}$. Bar graphs depict number of ramifications and total length $(\mu \mathrm{m})$ of the ramifications per neurosphere. Data are expressed as a mean \pm SEM. Measurements were done in approximately 20 nonoverlapping fields in each coverslip from five independent culture preparations using digital images (magnification, $\times 20$ ). *, $p<.05 ; * *, p<.01$ using the unpaired two-tailed Student's $t$ test for comparison with SVZ control cultures. (B): Representative fluorescent confocal photomicrographs of the P-SAPK/JNK (green), $\tau$ (red), and Hoechst 33342 (blue) staining in control cultures and in cultures exposed to 1 or $10 \mathrm{ng} / \mathrm{ml}$ TNF for $6 \mathrm{~h}$. Scale bars $=20 \mu \mathrm{m}$. Arrows depict P-SAPK/JNK and $\tau$ double labeling. Abbreviations: h, hours; min, minutes; TNF, tumor necrosis factor $\alpha$.

nous TNF- $\alpha$ promotes proliferation of oligodendrocyte progenitors in a mouse model of demyelination [32], as well as proliferation of neural progenitors residing in the SVZ/ventricular zone following TNF- $\alpha$ injection into the lateral ventricle of adult rat [30]. Thus, TNF- $\alpha$ is involved in regulating the turnover of neural stem/progenitor cells.
Because of the presence of the intracellular regions called death domains in the TNFR1, we hypothesize that high TNF- $\alpha$ concentrations could induce cell death. Thus, as assessed by TUNEL, 10 and $100 \mathrm{ng} / \mathrm{ml} \mathrm{TNF}-\alpha$, but not 0.3 and $1 \mathrm{ng} / \mathrm{ml} \mathrm{TNF}-\alpha$, induced cell death compared with the control cultures. These results suggest that $\mathrm{TNF}-\alpha$ at lower concentrations $(0.3$ and $1 \mathrm{ng} / \mathrm{ml})$ does not reach a 
threshold for activation of death domains; an alternative, but not mutually exclusive, scenario is that TNF- $\alpha$ may activate other downstream signaling pathways that do not necessarily induce cell death, depending on cell phenotype/differentiation. Accordingly, Cacci et al. [26] showed that TNF- $\alpha$ released from activated microglia, as well as exogenous added TNF- $\alpha$, at high concentrations $(20 \mathrm{ng} / \mathrm{ml})$, can promote the death of newly formed hippocampal progenitors in vitro [26]. Interestingly, and in accordance with our data, it was also reported that TNF- $\alpha(10 \mathrm{ng} / \mathrm{ml})$ was cytotoxic to SVZ neurospheres from adult mice [29].

To investigate the involvement of the SAPK/JNK pathway in response to TNF- $\alpha$, we performed immunocytochemistry using specific antibodies against the phosphorylated forms of SAPK/JNK kinase. We observed that TNF- $\alpha$ induced a robust change, in a time-dependent manner, of the subcellular localization of the activated (phosphorylated) forms of JNK, in SVZ cultures. After 15 minutes of incubation of SVZ cells with 1 and $10 \mathrm{ng} / \mathrm{ml} \mathrm{TNF}-\alpha$, we observed P-SAPK/JNK immunoreactivity translocation into the nucleus in a significant number of SVZ cells. However, after 6 hours of incubation at both TNF- $\alpha$ concentrations, a robust PSAPK/JNK immunoreactivity was observed on $\tau$-positive axons and growth cone-like structures extending out of neurospheres, but not in the nucleus. Moreover, TNF- $\alpha$ treatment increased the total length and the number of P-SAPK/JNK-positive ramifications. SAPK/JNK kinases are strongly activated in response to cytokines and stress stimuli $[47,48]$. In our model, JNK is initially activated following TNF- $\alpha$ exposure and translocates to the nucleus, where it can phosphorylate and activate several transcription factors, including c-Jun [49-51]. Activation of the JNK pathway has been associated with response to a diversity of stresses, and proapoptotic mechanisms [44]. Indeed, c-jun has been shown to transduce cell death signals [52-54]. However, the JNK pathway appears to mediate both proapoptotic and antiapoptotic functions, depending on the cell type, nature of stimulus, and strength of its activation [55]. Indeed, a growing body of literature supports a role of JNK in cell proliferation, survival, and differentiation [54-56]. It was shown that the JNK1 gene is involved in the repression of Wnt expression (Wnt is a known inhibitor of embryonic stem [ES] cell neurogenesis) and thus promotes neural differentiation of murine ES cells [57]. Also, disruption of the JNK pathway-specific scaffold protein JSAP1 in murine ES cells reduced neurogenesis in vitro [58]. Moreover, in differentiated neurons from wild-type embryoid bodies, JSAP1 was localized in the soma, neurites, and growth cone-like structures, and neurite outgrowth from the JSAP1-null embryoid bodies was apparently less prominent [58]. Recently, Kim et al. showed that interferon- $\gamma$ promotes neuronal differentiation characterized by neurite outgrowth and expression of neuronal markers of a neural progenitor cell line via the JNK pathway [59]. These reports are in agreement with our results showing that after 6 hours of incubation with TNF- $\alpha$, P-SAPK/ JNK immunoreactivity is found in $\tau$-positive axons and growth cone-like structures. Accordingly, $1 \mathrm{ng} / \mathrm{ml} \mathrm{TNF}-\alpha$ promotes both differentiation and maturation. Indeed, the increase in the number of NeuN-positive neurons following TNF- $\alpha$ treatment for 7 days (Fig. 3B) suggests an increase in neuronal commitment of progenitors. Moreover, SVZ cultures treated for 6 hours with TNF- $\alpha$ display a robust increase in P-JNK immunoreactivity in $\tau$-positive axons, consistently with neuronal maturation of neuroblasts. P-JNK immunoreactivity is closely associated with new differentiating axons ( $\tau$-positive) and is not associated with fully differentiated neurons. Thus, activated JNK also targets nonnuclear substrates, such as cytoskeletal proteins, neurofilaments, and actin, and so can modify cytoskeletal regulation, cell motility, axonogenesis, and neuronal polarization [60-66].

In the intact brain, concentrations of $\mathrm{TNF}-\alpha$ are low or barely detectable [67]. In accordance, in our experimental conditions, we were not able to find any effect of TNF- $\alpha$ at a 0.3 $\mathrm{ng} / \mathrm{ml}$ concentration on cell proliferation and differentiation. Furthermore, in SCCI studies, we incubated SVZ for 7 days with a neutralizing anti-TNF- $\alpha$ antibody to neutralize the biological effects of endogenously produced TNF- $\alpha$. Here again, levels of functional differentiation were similar to control levels, demonstrating that at physiological (i.e., low) levels, TNF- $\alpha$ modulates SVZ dynamics poorly. However, following brain injury or infection, circulating levels of TNF- $\alpha$ dramatically increase to levels close to the range of concentrations that we used in the present study $(1-100 \mathrm{ng} / \mathrm{ml})[67,68]$. This suggests that these concentrations are of robust pathophysiological relevance, and so TNF- $\alpha$ modulates neurogenesis mainly following brain injury and may be part of the repertoire of repairing factors released in the microenvironment that promote neuronal replacement from the SVZ pool of stem/progenitor cells.

\section{CONCLUSION}

The proneurogenic effect of TNF- $\alpha$ may open new perspectives for brain repair, highlighting the role of proinflammatory cytokines in neurogenesis and neuronal replacement in the damaged brain. We are currently conducting new studies in which SVZ neurospheres pretreated with $1 \mathrm{ng} / \mathrm{ml}$ TNF- $\alpha$ are transplanted into the hippocampal CA3 subfield in a rodent model of temporal lobe epilepsy. Our preliminary results (data not shown) reveal that TNF- $\alpha$-treated SVZ cells differentiate to some extent to doublecortin-positive neuroblasts. Thus, a better understanding of the effects of inflammatory conditions after brain injury or infection in neural stem cells, as well as a better knowledge of the signal transduction pathways activated in neurogenic and inflammatory conditions, will allow the development of new strategies to enhance neuronal differentiation and replacement using SVZ stem cells.

\section{ACKNOWLEDGMENTS}

This work was supported by FCT Portugal and FEDER, POCI/ NSE/58492/2004, PTDC/SAU-NEU/ 68465/2006, SFRH/BD/ 12731/2003, and FRH/PBD/26462/2006. We acknowledge Dr. Ana Paula Silva, Joana Gonçalves, and Sofia Baptista for help in Western blotting experiments.

\section{Disclosure of Potential Conflicts OF INTEREST}

The authors indicate no potential conflicts of interest.

\section{REFERENCES}

1 Luskin MB. Restricted proliferation and migration of postnatally generated neurons derived from the forebrain subventricular zone. Neuron 1993;11:173-189.

2 Doetsch F, Caillé I, Lim DA et al. Subventricular zone astrocytes are neural stem cells in the adult mammalian brain. Cell 1999;97:703-716.

3 Johansson CB, Momma S, Clarke DL et al. Identification of a neural stem cell in the adult mammalian central nervous system. Cell 1999;96: 25-34.

4 Alvarez-Buylla A, Garcia-Verdugo JM. Neurogenesis in adult subventricular zone. J Neurosci 2002;22:629-634. 
5 Kempermann G, Gast D, Kronenberg G et al. Early determination and long-term persistence of adult-generated new neurons in the hippocampus of mice. Development 2003;130:391-399.

6 Nait-Oumesmar B, Decker L, Lachapelle F et al. Progenitor cells of the adult mouse subventricular zone proliferate, migrate and differentiate into oligodendrocytes after demyelination. Eur J Neurosci 1999;11: 4357-4366.

7 Arvidsson A, Collin T, Kirik D et al. Neuronal replacement from endogenous precursors in the adult brain after stroke. Nat Med 2002;8: 963-970.

8 Parent JM, Vexler ZS, Gong C et al. Rat forebrain neurogenesis and striatal neuron replacement after focal stroke. Ann Neurol 2002;52: 802-813.

9 Picard-Riera N, Decker L, Delarasse C et al. Experimental autoimmune encephalomyelitis mobilizes neural progenitors from the subventricular zone to undergo oligodendrogenesis in adult mice. Proc Natl Acad Sci U S A 2002;99:13211-13216.

10 Jin K, Sun Y, Xie L et al. Directed migration of neuronal precursors into the ischemic cerebral cortex and striatum. Mol Cell Neurosci 2003;24: $171-189$.

11 Kokaia Z, Lindvall O. Neurogenesis after ischaemic brain insults. Curr Opin Neurobiol 2003;13:127-132.

12 Chen J, Magavi SS, Macklis JD. Neurogenesis of corticospinal motor neurons extending spinal projections in adult mice. Proc Natl Acad Sci U S A 2004;101:16357-16362.

13 Aarum J, Sandberg K, Haeberlein SL et al. Migration and differentiation of neural precursor cells can be directed by microglia. Proc Natl Acad Sci U S A 2003;100:15983-15988.

14 Ekdahl CT, Claasen JH, Bonde S et al. Inflammation is detrimental for neurogenesis in adult brain. Proc Natl Acad Sci U S A 2003;100: 13632-13637.

15 Monje ML, Toda H, Palmer TD. Inflammatory blockade restores adult hippocampal neurogenesis. Science 2003;302:1760-1765.

16 Aharoni R, Arnon R, Eilam R. Neurogenesis and neuroprotection induced by peripheral immunomodulatory treatment of experimental autoimmune encephalomyelitis. J Neurosci 2005;25:8217-8228.

17 Nguyen MD, Julien JP, Rivest S. Innate immunity: The missing link in neuroprotection and neurodegeneration? Nat Rev Neurosci 2002; 3:216-227.

18 Turrin NP, Rivest S. Tumor necrosis factor alpha but not interleukin 1beta mediates neuroprotection in response to acute nitric oxide excitotoxicity. J Neurosci 2006;26:143-151.

19 Fontaine V, Mohand-Said S, Hanoteau N et al. Neurodegenerative and neuroprotective effects of tumor necrosis factor (TNF) in retinal ischemia: Opposite roles of TNF receptor 1 and TNF receptor 2. J Neurosci 2002;22:RC216.

20 Yang L, Lindholm K, Konishi Y et al. Target depletion of distinct tumor necrosis factor receptor subtypes reveals hippocampal neuron death and survival through different signal transduction pathways. J Neurosci 2002; 22:3025-3032.

21 Marchetti L, Klein M, Schlett K et al. Tumor necrosis factor (TNF)mediated neuroprotection against glutamate induced excitotoxicity is enhanced by N-methyl-D-aspartate receptor activation. Essential role of a TNF receptor 2-mediated phosphatidylinositol 3-kinase-dependent NFkappa B pathway. J Biol Chem 2004;279:32869-32881.

22 Bernardino L, Xapelli S, Silva AP et al. Modulator effects of interleukin-1 beta and tumor necrosis factor-alpha on AMPA-induced excitotoxicity in mouse organotypic hippocampal slice cultures. J Neurosci 2005; 25:6734-6744.

23 Klassen HJ, Imfeld KL, Kirov II et al. Expression of cytokines by multipotent neural progenitor cells. Cytokine 2003;22:101-106.

24 Iosif RE, Ekdahl CT, Ahlenius $\mathrm{H}$ et al. Tumor necrosis factor receptor 1 is a negative regulator of progenitor proliferation in adult hippocampal neurogenesis. J Neurosci 2006;26:9703-9712.

25 Ben-Hur T, Ben-Menachem O, Furer V et al. Effects of proinflammatory cytokines on the growth, fate, and motility of multipotential neural precursor cells. Mol Cell Neurosci 2003;24:623-631.

26 Cacci E, Claasen JH, Kokaia Z. Microglia-derived tumor necrosis factoralpha exaggerates death of newborn hippocampal progenitor cells in vitro. J Neurosci Res 2005;80:789-797.

27 Sheng WS, Hu S, Ni HT et al. TNF-alpha-induced chemokine production and apoptosis in human neural precursor cells. J Leukoc Biol 2005;78: 1233-1241.

28 Widera D, Mikenberg I, Elvers $M$ et al. Tumor necrosis factor alpha triggers proliferation of adult neural stem cells via IKK/NF-kappaB signaling. BMC Neurosci 2006;7:64.

29 Wong G, Goldshmit Y, Turnley AM. Interferon-gamma but not TNF alpha promotes neuronal differentiation and neurite outgrowth of murine adult neural stem cells. Exp Neurol 2004;187:171-177.

$30 \mathrm{Wu}$ J, Kuo J, Liu Y et al. Tumor necrosis factor- $\alpha$ modulates the proliferation of neural progenitors in the subventricular/ventricular zone of adult rat brain. Neurosci Lett 2000;292:203-206.

31 Heldmann U, Thored P, Claasen JH et al. TNF-alpha antibody infusion impairs survival of stroke-generated neuroblasts in adult rat brain. Exp Neurol 2005;196:204-208

32 Arnett HA, Mason J, Marino M et al. TNF alpha promotes proliferation of oligodendrocyte progenitors and remyelination. Nat Neurosci 2001;4: 1116-1122.

33 Obregón E, Punzon C, Fernandez-Cruz E et al. HIV-1 infection induces differentiation of immature neural cells through autocrine tumor necrosis factor and nitric oxide production. Virology 1999;261:193-204.

34 Obregón E, Punzon MC, Gonzalez-Nicolas J et al. Induction of adhesion/ differentiation of human neuroblastoma cells by tumour necrosis factoralpha requires the expression of an inducible nitric oxide synthase. Eur J Neurosci 1997;9:1184-1193.

35 Agasse F, Roger M, Coronas V. Neurogenic and intact or apoptotic non-neurogenic areas of adult brain release diffusible molecules that differentially modulate the development of subventricular zone cell cultures. Eur J Neurosci 2004;19:1459-1468.

36 Takeuchi $\mathrm{H}$, Jin $\mathrm{S}$, Wang $\mathrm{J}$ et al. Tumor necrosis factor-alpha induces neurotoxicity via glutamate release from hemichannels of activated microglia in an autocrine manner. J Biol Chem 2006;281:21362-21368.

37 Otsuki Y, Li Z, Shibata MA. Apoptotic detection methods-from morphology to gene. Prog Histochem Cytochem 2003;38:275-339.

38 Agasse F, Bernardino L, Silva BA et al. Response to histamine allows the functional identification of neuronal progenitors, neurons, astrocytes and immature cells in subventricular zone cell cultures. Rejuvenation Res 2008;11:187-200

39 Ambrósio AF, Silva AP, Malva JO et al. Role of desensitization of AMPA receptors on the neuronal viability and on the $\left[\mathrm{Ca}^{2+}\right]_{\mathrm{i}}$ changes in cultured rat hippocampal neurons. Eur J Neurosci 2000;12:2021-2031.

40 Tran PB, Ren D, Veldhouse TJ et al. Chemokine receptors are expressed widely by embryonic and adult neural progenitor cells. J Neurosci Res 2004;76:20-34

41 Gage FH. Mammalian neural stem cells. Science 2000;287:1433-1438.

42 Stefferl A, Hopkins SJ, Rothwell NJ et al. The role of TNF-alpha in fever: Opposing actions of human and murine TNF-alpha and interactions with IL-beta in the rat. Br J Pharmacol 1996;118:1919-1924.

43 MacEwan DJ. TNF receptor subtype signalling: Differences and cellular consequences. Cell Signal 2002;14:477-492.

44 Varfolomeev EE, Ashkenazi A. Tumor necrosis factor: An apoptosis JuNKie? Cell 2004;116:491-497.

45 Hikawa N, Kiuchi Y, Maruyama T et al. Delayed neurite regeneration and its improvement by nerve growth factor (NGF) in dorsal root ganglia from MRL-lpr/lpr mice in vitro. J Neurol Sci 1997;149:13-17.

46 Desbarats J, Birge RB, Mimouni-Rongy M et al. Fas engagement induces neurite growth through ERK activation and p35 upregulation. Nat Cell Biol 2003;5:118-125.

47 Roux PP, Blenis J. ERK and p38 MAPK-activated protein kinases: A family of protein kinases with diverse biological functions. Microbiol Mol Biol Rev 2004;68:320-344.

48 Bode AM, Dong Z. The functional contrariety of JNK. Mol Carcinog 2007;46:591-598

49 Mizukami Y, Yoshioka K, Morimoto S et al. A novel mechanism of JNK1 activation. Nuclear translocation and activation of JNK1 during ischemia and reperfusion. J Biol Chem 1997;272:16657-16662.

50 Kyriakis JM, Avruch J. Mammalian mitogen-activated protein kinase signal transduction pathways activated by stress and inflammation. Physiol Rev 2001;81:807-869.

51 Weston CR, Davis RJ. The JNK signal transduction pathway. Curr Opin Genet Dev 2002;12:14-21.

52 Behrens A, Sibilia M, Wagner EF. Amino-terminal phosphorylation of c-Jun regulates stress-induced apoptosis and cellular proliferation. Nat Genet 1999;21:326-329.

53 Whitfield J, Neame SJ, Paquet L et al. Dominant-negative c-Jun promotes neuronal survival by reducing BIM expression and inhibiting mitochondrial cytochrome c release. Neuron 2001;29:629-643.

54 Karin M, Gallagher E. From JNK to pay dirt: Jun kinases, their biochemistry, physiology and clinical importance. IUBMB Life 2005;57:283-295.

55 Heasley LE, Han SY. JNK regulation of oncogenesis. Mol Cells 2006; 21:167-173.

56 Waetzig V, Czeloth K, Hidding U et al. c-Jun N-terminal kinases (JNKs) mediate pro-inflammatory actions of microglia. Glia 2005;50:235-246.

57 Amura CR, Marek L, Winn RA et al. Inhibited neurogenesis in JNK1deficient embryonic stem cells. Mol Cell Biol 2005;25:10791-10802.

$58 \mathrm{Xu} \mathrm{P}$, Yoshioka K, Yoshimura D et al. In vitro development of mouse embryonic stem cells lacking JNK/stress-activated protein kinase-associated protein 1 (JSAP1) scaffold protein revealed its requirement during early embryonic neurogenesis. J Biol Chem 2003;278:48422-48433.

59 Kim SJ, Son TG, Kim K et al. Interferon-gamma promotes differentiation of neural progenitor cells via the JNK pathway. Neurochem Res 2007;32:1399-1406.

60 Yao R, Yoshihara M, Osada H. Specific activation of a c-Jun NH2terminal kinase isoform and induction of neurite outgrowth in PC-12 cells by staurosporine. J Biol Chem 1997;272:18261-18266.

61 Kita Y, Kimura KD, Kobayashi M et al. Microinjection of activated 
phosphatidylinositol-3 kinase induces process outgrowth in rat PC12 cells through the Rac-JNK signal transduction pathway. J Cell Sci 1998;111:907-915.

62 Chang L, Jones Y, Ellisman MH et al. JNK1 is required for maintenance of neuronal microtubules and controls phosphorylation of microtubuleassociated proteins. Dev Cell 2003;4:521-533.

63 Yoshida H, Hastie CJ, McLauchlan $\mathrm{H}$ et al. Phosphorylation of microtubule-associated protein tau by isoforms of c-Jun N-terminal kinase (JNK). J Neurochem 2004;90:352-358.

64 Xia Y, Karin M. The control of cell motility and epithelial morphogenesis by Jun kinases. Trends Cell Biol 2004;14:94-101.

65 Björkblom B, Ostman N, Hongisto V et al. Constitutively active cyto- plasmic c-Jun $\mathrm{N}$-terminal kinase 1 is a dominant regulator of dendritic architecture: Role of microtubule-associated protein 2 as an effector. J Neurosci 2005;25:6350-6361

66 Oliva AA, Atkins CM, Copenagle L et al. Activated c-Jun N-terminal kinase is required for axon formation. J Neurosci 2006;26:9462-9470.

67 Pollmächer T, Haack M, Schuld A et al. Low levels of circulating inflammatory cytokines-do they affect human brain functions? Brain Behav Immun 2002; 16:525-532.

68 Gianinazzi C, Grandgirard D, Imboden H et al. Caspase-3 mediates hippocampal apoptosis in pneumococcal meningitis. Acta Neuropathol 2003; 105:499-507. 